\title{
Correction to: High IRF8 expression correlates with CD8 T cell infiltration and is a predictive biomarker of therapy response in ER-negative breast cancer
}

Gerardo Gatti ${ }^{1,2 *}$, Courtney Betts ${ }^{3}$, Darío Rocha ${ }^{4}$, Maribel Nicola ${ }^{1}$, Verónica Grupe ${ }^{1}$, Cecilia Ditada ${ }^{1}$, Nicolas G. Nuñez ${ }^{5}$, Emiliano Roselli' ${ }^{6}$, Paula Araya ${ }^{6}$, Jeremías Dutto ${ }^{6}$, Lucia Boffelli', Elmer Fernández ${ }^{2,7}$, Lisa M. Coussens ${ }^{3}$ and Mariana Maccioni ${ }^{6}$

Correction to: Breast Cancer Res 23, 40 (2021) https://doi.org/10.1186/s13058-021-01418-7

After publication of the original article [1], the authors identified some errors in the authors' affiliations list. The correct affiliations are below listed:

Lisa M Cussens (3)

3) Department of Cell, Developmental \& Cancer Biology, Knight Cancer Institute, Oregon Health \& Science University, Portland, Oregon, USA

Elmer Fernández $(2,7)$

2) Consejo Nacional de Investigaciones Científicas y Técnicas (CONICET)

7) CIDIE-CONICET, Universidad Católica de Córdoba, Córdoba, Argentina

Mariana Maccioni (6)

6) Departamento de Bioquímica Clínica, Centro de Investigaciones en Bioquímica Clínica e Inmunología (CIBICI), Consejo Nacional de Investigaciones Científicas y Técnicas (CONICET), Facultad de Ciencias Químicas, Universidad Nacional de Córdoba, Córdoba 5000, Argentina
The original article has been corrected.

\begin{abstract}
Author details
'Laboratorio de Investigación en Cáncer, Fundación para el progreso de la Medicina, X5000EMS, Córdoba, Argentina. ${ }^{2}$ Consejo Nacional de Investigaciones Científicas y Técnicas (CONICET), Buenos Aires, Argentina. ${ }^{3}$ Department of Cell, Developmental \& Cancer Biology, Knight Cancer Institute, Oregon Health \& Science University, Portland, OR, USA. ${ }^{4}$ Facultad de Ciencias Exactas, Físicas y Naturales, Universidad Nacional de Córdoba, Córdoba, Argentina. ${ }^{5}$ Institute of Experimental Immunology, University of Zurich, Zurich, Switzerland. ${ }^{6}$ Departamento de Bioquímica Clínica, Centro de Investigaciones en Bioquímica Clínica e Inmunología (CIBICI), Consejo Nacional de Investigaciones Científicas y Técnicas (CONICET), Facultad de Ciencias Químicas, Universidad Nacional de Córdoba, 5000 Córdoba, Argentina. ${ }^{7}$ CIDIE-CONICET, Universidad Católica de Córdoba, Córdoba, Argentina
\end{abstract}

Published online: 22 April 2021

Reference

1. Gatti G, et al. High IRF8 expression correlates with CD8 T cell infiltration and is a predictive biomarker of therapy response in ER-negative breast cancer. Breast Cancer Res. 2021;23:40 https://doi.org/10.1186/s13058-021-01418-7.

The original article can be found online at https://doi.org/10.1186/s13058021-01418-7.

* Correspondence: gerardogatti@fpmlab.org.ar

'Laboratorio de Investigación en Cáncer, Fundación para el progreso de la Medicina, X5000EMS, Córdoba, Argentina

${ }^{2}$ Consejo Nacional de Investigaciones Científicas y Técnicas (CONICET), Buenos Aires, Argentina

Full list of author information is available at the end of the article

(c) The Author(s). 2021 Open Access This article is licensed under a Creative Commons Attribution 4.0 International License, which permits use, sharing, adaptation, distribution and reproduction in any medium or format, as long as you give appropriate credit to the original author(s) and the source, provide a link to the Creative Commons licence, and indicate if changes were made. The images or other third party material in this article are included in the article's Creative Commons licence, unless indicated otherwise in a credit line to the material. If material is not included in the article's Creative Commons licence and your intended use is not permitted by statutory regulation or exceeds the permitted use, you will need to obtain permission directly from the copyright holder. To view a copy of this licence, visit http://creativecommons.org/licenses/by/4.0/ The Creative Commons Public Domain Dedication waiver (http://creativecommons.org/publicdomain/zero/1.0/) applies to the data made available in this article, unless otherwise stated in a credit line to the data. 